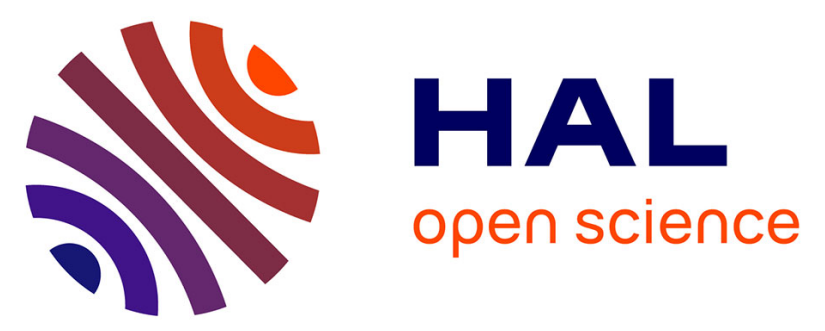

\title{
Analysis by high throughput sequencing of Specific Pathogen Free eggs
}

Léa Gagnieur, Justine Cheval, Marielle Bernoin-Cochet, Emmanuel Bréard, Marlène Gratigny, Charles Hébert, Erika Muth, Cyril Viarouge, Marine

Dumarest, Muriel Coulpier, et al.

\section{To cite this version:}

Léa Gagnieur, Justine Cheval, Marielle Bernoin-Cochet, Emmanuel Bréard, Marlène Gratigny, et al.. Analysis by high throughput sequencing of Specific Pathogen Free eggs. Biologicals, 2014, 42 (4), pp.1045-1056. 10.1016/j.biologicals.2014.05.004 . hal-01190009

\section{HAL Id: hal-01190009 \\ https://hal.science/hal-01190009}

Submitted on 1 Sep 2015

HAL is a multi-disciplinary open access archive for the deposit and dissemination of scientific research documents, whether they are published or not. The documents may come from teaching and research institutions in France or abroad, or from public or private research centers.
L'archive ouverte pluridisciplinaire HAL, est destinée au dépôt et à la diffusion de documents scientifiques de niveau recherche, publiés ou non, émanant des établissements d'enseignement et de recherche français ou étrangers, des laboratoires publics ou privés. 
Short paper

\title{
Analysis by high throughput sequencing of Specific Pathogen Free eggs
}

\author{
Léa Gagnieur ${ }^{\text {a }}$, Justine Cheval ${ }^{\mathrm{b}}$, Marielle Cochet ${ }^{\mathrm{c}}$, Emmanuel Breard ${ }^{\mathrm{c}}$, \\ Marlène Gratigny ${ }^{\mathrm{b}}$, Charles Hébert ${ }^{\mathrm{b}}$, Erika Muth ${ }^{\mathrm{b}}$, Cyril Viarouge ${ }^{\mathrm{c}}$, \\ Marine Dumarest ${ }^{\mathrm{a}}$, Muriel Coulpier ${ }^{\mathrm{c}}$, Marc Eloit ${ }^{\mathrm{a}, \mathrm{b}, \mathrm{c},{ }^{*}}$ \\ a Institut Pasteur, Laboratory of Pathogen Discovery, Department of Virology, 28 rue du Docteur Roux, F-75724 Paris, France \\ b PathoQuest, Bâtiment François Jacob, 25 rue du Dr Roux, 75015, Paris, France \\ c Ecole Nationale Vétérinaire d'Alfort, UMR 1161 Virologie ENVA, INRA, ANSES, 7 Avenue Général de Gaulle, F-94704 Maisons Alfort, France
}

\section{A R T I C L E I N F O}

\section{Article history:}

Received 9 January 2014

Received in revised form 11 April 2014

Accepted 15 May 2014

Available online $\mathrm{xxx}$

\section{Keywords:}

Chicken

Egg

Specific Pathogen Free

High throughput sequencing

Virus safety

Vaccines

\begin{abstract}
A B S T R A C T
Specific Pathogen Free (SPF) embryonated eggs are used for the production of many veterinary and human vaccines. We have used High Throughput Sequencing to screen allantoic fluids and embryos for the presence of encapsidated viral genomes and viral transcripts, respectively. SPF eggs from two different producers were tested. We evidenced sequences corresponding to known endogenous retroviruses and sequences of Avian Leukosis Virus, but no sequence that might suggest a productive infection of eggs with a virus even distant from known viruses. Our results strongly suggest that SPF eggs such as those used for this study represent a safe substrate for the production of vaccines.
\end{abstract}

(C) 2014 The International Alliance for Biological Standardization. Published by Elsevier Ltd. All rights reserved.
Specific Pathogen Free embryonated eggs are used for the production of many veterinary and human vaccines. The chickens are bred under strict contained atmosphere and controlled periodically regarding the lack of virus infection according to relevant guidelines $[1,2]$. This is specifically important as SPF eggs are used for the manufacturing of some live vaccines, for which there is no downstream virus-inactivating step. Importantly, knowledge regarding chicken viruses is derived from veterinary medicine and is therefore biased towards viruses pathogenic for chicken, which is not relevant for other hosts. Unbiased detection of viruses might thus increase the safety of the products.

We have used the potency of High Throughput Sequencing (HTS) to screen SPF eggs from two different producers (A and B). Two independent pools of 14 eggs from producer $A$ and 11 eggs from producer $B$ were tested for the presence of viral transcripts

* Corresponding author. Institut Pasteur, Laboratory of Pathogen Discovery, Department of Virology, 28 rue du Docteur Roux, F-75724 Paris, France. Tel.: +33 1 44389216.

E-mail address: marc.eloit@pasteur.fr (M. Eloit). from the embryos and viral DNA or RNA from allantoic fluids. RNAs from embryos were extracted, converted to cDNA using random priming and random amplified as previously described [3]. DNA and RNA extracted from allantoic fluids [4] were processed similarly. High molecular weight DNAs resulting from amplification of the eggs nucleic acids from the same provider were then sequenced with an Illumina ${ }^{\circledR}$ HiSeq-2000 sequencer (DNAVision, Gosselies, Belgium). The sequencing depth was respectively of 70.2 and 91.5 million paired-end reads of $101 \mathrm{nt}$ in length for the A and B pools. Sequences were trimmed and filtered according to their quality score and the chicken genome sequence galGal4 (ICGSC Gallus_gallus-4.0 (GCA_000002315.2)) was subtracted. Finally, de novo assembly and taxonomic assignation of contigs were conducted as previously described [5].

We evidenced contigs corresponding to endogenous retroviruses (A: 299 reads in 20 contigs, B: 385 reads in 25 contigs), which confirm previous findings: defective and non-defective loci of endogenous retroviruses are present in chicken primary fibroblasts used for the production of vaccines. Viral infectious particles were 
associated with both defective and intact sequences [6] and different loci are capable of expressing viral proteins, such as p19 and p27 [7]. We also identified alpharetrovirus sequences, but none from gammaretrovirus (avian reticuloendotheliosis virus [8]). Exogenous alpharetroviruses may be transmitted horizontally between chickens or after in ovo infection. Sequences evidenced in our study were from Avian Leukosis Virus (ALV) (A : 593 reads in 39 contigs, B : 1008 reads in 44 contigs), a virus responsible for lymphoid tumors and other disorders (reviewed in Ref. [9]). It is well known that sequences of ALV-E exist integrated in the genome of chicken germ line and can therefore be vertically transmitted, as those of strictly endogenous viruses described above. Since SPF herds are screened for the lack of ALV of at least groups A, B and J [1] [2], these sequences correspond likely to endogenous proviruses. We also evidenced hits wrongly attributed by the blast analysis to Avian Myeloblastosis Virus (AMV), Myeoloblastosis Associated Virus (MAV) [10], avian myelocytomatosis virus [11] and to Rous Sarcoma Virus (reviewed in Ref. [12]), and different sarcoma viruses belonging to the src family like Y73. All of these hits corresponded to sequences identical to cellular oncogens like c-src, c-myb, c-raf without any hit to gag, pol ou env gene, which reinforce their nonviral origin. Our results are consistent for the presence of retroviruses already known as endogenous retroviruses and further suggest that no other retrovirus has been spreading horizontally in these herds at the time of sampling.

Additionally, we did not evidence productive infection of other known or unknown viruses. Indeed, we detected only 7 (A pool) and 5 (B pool) contigs of large size (>1000 nt) without any taxonomic assignation. Ten of them contained only short open reading frames (orf) ( $<75$ amino acids) while the 2 others each had one orf of either 100 or 131 amino acids. None ORF had homology with known viral proteins. We did not identify shorter contigs that could be mapped along a common distant reference, as we had done previously for the discovery of other viruses. Indeed, the pipeline used for virus detection in allantoic fluids has a broad and sensitive range of detection [3]. It is able to identify unknown viruses [13,14], including those distant from known viruses that define new viral genus [15]. We also evaluated the level of detection of the transcriptome pipeline dedicated to embryos using a known virus present in databases: blinded transcriptome analysis of Vero cells infected at a very low multiplicity of infection ( $0.025 \mathrm{pfu} / \mathrm{cell})$ with the Borna Disease virus, a non cytolytic enveloped RNA virus, allowed the detection of infection two days post infection. The virus was identified at the same time by immunofluorescence analysis and RT-PCR [16,17]. Our results strongly suggest that the hypothesis of productive infection of eggs with a virus even distant from known viruses is highly unlikely. It remains however possible that low level of expression of transcripts by latent viruses, far from known viruses, could escape HTS-based detection. Such a pipeline might also be used after amplification in susceptible cells [18,19], which are also useful to characterize adventitious viruses when HTS suggests their presence.

Taken together, our results strongly suggest that SPF eggs such as those used for this study represent a safe substrate for the production of vaccines.

\section{Acknowledgments}

This work received financial support from the foundation Biosecure, Paris and Labex IBEID.

\section{References}

[1] FDA. Eggs and chickens for production of veterinary biological products; September 20, 2002 [n.d.].

[2] European Pharmacopea 07/2010: 50202 5.2.2. Chicken flocks free from specified pathogens for the production and quality control of vaccines, [n.d.].

[3] Cheval J, Sauvage V, Frangeul L, Dacheux L, Guigon G, Dumey N, et al. Evaluation of high-throughput sequencing for identifying known and unknown viruses in biological samples. J Clin Microbiol 2011;49:3268-75. http:// dx.doi.org/10.1128/JCM.00850-11.

[4] Vayssier-Taussat M, Moutailler S, Michelet L, Devillers E, Bonnet S, Cheval J, et al. Next generation sequencing uncovers unexpected bacterial pathogens in ticks in Western europe. PloS One 2013;8:e81439. http://dx.doi.org/10.1371/ journal.pone.0081439.

[5] Gagnieur L, Cheval J, Gratigny M, Hébert C, Muth E, Dumarest M, et al. Unbiased analysis by high throughput sequencing of the viral diversity in fetal bovine serum and trypsin used in cell culture. Biologicals; 2014:1045. http:// dx.doi.org/10.1016/j.biologicals.2014.02.002.

[6] Johnson JA, Heneine W. Characterization of endogenous avian leukosis viruses in chicken embryonic fibroblast substrates used in production of measles and mumps vaccines. J Virol 2001;75:3605-12. http://dx.doi.org/10.1128/ JVI.75.8.3605-3612.2001.

[7] McNally MM, Wahlin KJ, Canto-Soler MV. Endogenous expression of ASLV viral proteins in specific pathogen free chicken embryos: relevance for the developmental biology research field. BMC Dev Biol 2010;10:106. http:/ dx.doi.org/10.1186/1471-213X-10-106.

[8] Niewiadomska AM, Gifford RJ. The extraordinary evolutionary history of the reticuloendotheliosis viruses. PLoS Biol 2013;11:e1001642. http://dx.doi.org/ 10.1371/journal.pbio.1001642.

[9] Payne LN, Nair V. The long view: 40 years of avian leukosis research, Avian Pathol J WVPA 2012;41:11-9. http://dx.doi.org/10.1080/03079457.2011.646237.

[10] Perbal B. Avian myeoloblastosis virus (AMV): only one side of the coin. Retrovirology 2008;5:49. http://dx.doi.org/10.1186/1742-4690-5-49.

[11] Filchev A, Bozhkov S, Karakoz I, Plachy J, Sotirov N. Pathogenicity of avian myelocytomatosis virus MC29 in two lines of chickens. Avian Pathol 1993;22: 295-310. http://dx.doi.org/10.1080/03079459308418922.

[12] Rubin H. The early history of tumor virology: Rous, RIF, and RAV. Proc Natl Acad Sci U S A 2011;108:14389-96. http://dx.doi.org/10.1073/pnas.1108655108.

[13] Sauvage V, Cheval J, Foulongne V, Gouilh MA, Pariente K, Manuguerra JC, et al. Identification of the first human gyrovirus, a virus related to chicken anemia virus. J Virol 2011;85:7948-50. http://dx.doi.org/10.1128/JVI.00639-11.

[14] Sauvage V, Foulongne V, Cheval J, Ar Gouilh M, Pariente K, Dereure O, et al. Human polyomavirus related to African green monkey lymphotropic polyomavirus. Emerg Infect Dis 2011;17:1364-70. http://dx.doi.org/10.3201/ eid1708.110278.

[15] Sauvage V, Ar Gouilh M, Cheval J, Muth E, Pariente K, Burguiere A, et al A member of a new Picornaviridae genus is shed in pig feces. J Virol 2012;86: 10036-46. http://dx.doi.org/10.1128/JVI.00046-12.

[16] Brnic D, Stevanovic V, Cochet M, Agier C, Richardson J, Montero-Menei CN et al. Borna disease virus infects human neural progenitor cells and impairs neurogenesis. J Virol 2012;86:2512-22. http://dx.doi.org/10.1128/ JVI.05663-11.

[17] Cabannes E, Hébert C, Eloit M. Whole genome - next generation sequencing as a virus safety test for biotechnological products, PDA Journal of Pharmaceutical Science and Technology, in press.

[18] Maas R, van Zoelen D, Oei H, Claassen I. Replacement of primary chicken embryonic fibroblasts (CEF) by the DF-1 cell line for detection of avian leucosis viruses. Biologicals 2006;34:177-81.

[19] Birmingham CL, Dupont D, Riou P, Armanet C, Edamura KN, Martinho B, et al Detection of avian retroviruses in vaccines by amplification on DF-1 cells with immunostaining and fluorescent product-enhanced reverse transcriptase endpoint methods. J Clin Microbiol 2013;51:1496-504. http://dx.doi.org/ 10.1128/JCM.03146-12. 